\title{
Modification of poly(vinyl chloride) by aromatic amines: application to the extraction of some metal cations
}

\author{
Adnen Mabrouki ${ }^{1)}$, Fayçel Ammari ${ }^{1), ~ *) ~(O R C I D ~ I D: ~ 0000-0003-3541-0854) ~}$ \\ DOI: dx.doi.org/10.14314/polimery.2021.7.2
}

\begin{abstract}
The reaction of poly(vinyl chloride) (PVC) with various aliphatic amines in 1,4-dioxane has been studied. These reactions led to the formation of new polymers (PVC-L), which were characterized by different spectroscopic methods: differential thermal analysis (DTA) and infrared. The extraction percentages were determined by comparing the initial conductivity of the aqueous solution containing the studied metal with the final conductivity of the aqueous solution at extraction equilibrium. One of the obtained polymers gave an extraction rate of $82.05 \%$ for $\mathrm{Li}+$, which underlines the importance of the substitution of chlorine atoms by diethylenetriamine groups. A kinetic study of the extraction shows that the optimal duration of extraction was obtained with the polymer most substituted by diethylenetriamine groups.
\end{abstract}

Keywords: poly(vinyl chloride) (PVC), functionalization, metal cation, extraction, diethylenetriamine, substitution reaction.

\section{Modyfikacja poli(chlorku winylu) aminami aromatycznymi: zastosowanie wybranych kationów metali do ekstrakcji}

Streszczenie: Badano reakcję poli(chlorku winylu) (PVC) z różnymi aminami alifatycznymi w 1,4-dioksanie. Reakcje te doprowadziły do powstania nowych polimerów (PVC-L), które charakteryzowano metodami różnicowej analizy termicznej (DTA) i podczerwieni. Procent ekstrakcji określano przez porównanie początkowej przewodności roztworu wodnego zawierającego badany metal z końcową przewodnością roztworu wodnego w stanie równowagi ekstrakcji. Dla jednego z otrzymanych polimerów uzyskano stopień ekstrakcji 82, 05\% dla Li +, co podkreśla znaczenie podstawienia atomów chloru przez grupy dietylenotriaminowe. Badania kinetyczne wykazały, że optymalny czas ekstrakcji uzyskano dla polimeru z najbardziej podstawionym grupami dietylenotriaminowymi.

Słowa kluczowe: poli(chorek winylu) (PVC), funkcjonalizacja, kation metali, ekstrakcja, dietylenotriamina, reakcja substytucji.

Poly(vinyl chloride) has been used in various fields such as construction, household appliances, packaging, electrical and electronic products, automobile, furniture, etc. A huge amount of PVC waste has been discarded both in the post-manufacturing and post-consumer phases. Worldwide, PVC waste can be managed primarily through landfill $(82 \%)$ and incineration $(15 \%)[1,2]$. On the other hand PVC finds many applications in the medical field, blood storage bags and their components [3]. PVC is not a polymer compatible with blood, one of the techniques which exists consists in improving this biocompatibility, what includes the polymer surface modification existing the end point of heparin [4, 5]. The animation of PVC was followed by complexation with heparin

\footnotetext{
1) University of Carthage, Faculty of Sciences of Bizerte, Laboratory of Organic Synthesis, Jarzouna, Bizerte 7021, Tunisia.

*) Author for correspondence: ammari1971@gmail.com
}

$[6,7]$, grafting of hydrophilic polymers on the surface of PVC [8] and modification of the plasma [9]. In another work, PVC was modified for the treatment of wastewater contaminated with cadmium [10]. PVC is also used for recycling of a used lithium-ion batteries (LIB) by a mechanical-chemical process [11, 12].

In this work, given that the pollution of the aquatic environment by heavy metals from industrial and consumer waste is considered as a threat to aquatic organisms and to human health, we focused our work in laboratory on the synthesis of new materials from PVC in order to extract metal cations. Several polymer-based products have been synthesized [13-18]. Several chemical reactions have been applied such as substitution, elimination, reduction and degradation. Nucleophilic substitution is the most studied reaction [13], Abdelaal and Sobahi made substitutions of PVC chlorine by I then by $\mathrm{OH}$ in a solution of DMF. Navarro et al. carried out the modification of PVC with several aromatic thiols. This 
work is devoted to the modification of polyvinyl chloride $\left(\mathrm{P}_{0}\right)$ by aromatic amines and to the study of the complexing and catalytic properties of various modified polymers [14].

In the present work, we have synthesized new products by grafting amino-alkyl and amino-aryl groups onto $\mathrm{P}_{0}$ for use in the extraction of the two metal cations cadmium and lithium which are widespread in the environment and known to be harmful to human health.

\section{EXPERIMENTAL PART}

\section{Materials}

Commercial PVC $\left(\mathrm{P}_{0}\right) \quad(\mathrm{Mr}=48$ 000) was purchased from Fluka. 1,4-dioxan, triethylamine, N,N Dimethylformamide (DMF), diethylenetriamine (99\%), 4-aminovératrole, 4-aminophenol, diethyl ether and $\mathrm{LiBr}$ was produced by Sigma-Aldrich. $\mathrm{CdCl}_{2} \cdot \mathrm{H}_{2} \mathrm{O}(98 \%)$ was provided by Fluka. Diethyl ether was bought from Panreac. Potassium iodide (KI) and sodium hydroxide $(\mathrm{NaOH})$ were purchased from Prolabo.

\section{Chemical functionalization of PVC}

In order to make the polymer $\left(\mathrm{P}_{0}\right)$ more reactive, we performed the Conant-Finkelstein reaction to replace the chlorine atoms of pure PVC with iodine atoms using a nucleophilic substitution mechanism [20].

\section{Extraction of some metal ions}

The work included the use of polymers modified with amine groups to remove metal ions $\left(\mathrm{Li}^{+}, \mathrm{Cd}^{2+}\right)$ by solid phase extraction (SPE).

\section{Extraction study}

In a $30 \mathrm{~mL}$ vial, $20 \mathrm{~mL}$ of an aqueous metal salt solution $\left(5 \cdot 10^{-4} \mathrm{M}\right)$ was mixed with $100 \mathrm{mg}$ of each powdered polymer. Carefully, the mixture was stirred and the initial conductivity $\left(\sigma_{0}\right)$ was measured.

\section{Percentage of extraction}

The results of the metal ion extraction for each synthesized polymer were expressed as percentages of their initial concentration.

The metal ion percentage was calculated using the following equation.

$$
E=[(C i-C f) / C i] \cdot 100 \%
$$

where: $\mathrm{Ci}\left(\mathrm{mol} / \mathrm{cm}^{3}\right)$ is the initial concentration of metals in aqueous solution and $C f\left(\mathrm{~mol} / \mathrm{cm}^{3}\right)$ is the final concentration of the metal in the aqueous solution at equilibrium extraction.

\section{Testing methods}

The infrared analysis using the (ATR FT-IR) technique was carried out on a Thermo Scientific Nicolet FTIR 200 spectrophotometer with a scanning range between 4000 and $400 \mathrm{~cm}^{-1}$.

Differential thermal analysis (DTA) was performed on a SETARAM TGA 92 device. The $\mathrm{pH}$ was measured with a $\mathrm{pH} /$ conductivity meter, VWR / CO 3000L.

\section{Synthesis of veratrole PVC-amine $P_{1}$}

$5 \mathrm{~g}$ of $\mathrm{PVC}\left(\mathrm{Mw}=48,000 \mathrm{gmol}^{-1}\right), 1 \mathrm{~g}$ of potassium iodide and $100 \mathrm{ml}$ of 1,4-dioxane were introduced into a bomb to hydrogenate and stirred at room temperature. Then $60 \mathrm{mg}$ of 4 -aminoveratrole and $2 \mathrm{ml}$ of triethylamine were introduced. This mixture was stirred until the medium was homogenized. Then it was allowed to react at $100^{\circ} \mathrm{C}$ for 24 hours. At the end of the reaction, it was washed several times with distilled water. It was observed that two rubbery phases appeared:

A white phase which would be noted as sample 1 subsequently.

A brown phase which would be noted sample 2 later. Each phase is washed several times with distilled water and then with diethyl ether. The synthesized polymer $\mathrm{P}_{1}$ had a mass of $4.43 \mathrm{~g}$ and white in color.

\section{Synthesis of polymer $P_{2}$}

$5 \mathrm{~g}$ of commercial PVC $\left(\mathrm{P}_{0}\right), 1.16 \mathrm{~g}$ of $\mathrm{KI}$ and $100 \mathrm{ml}$ of 1,4-dioxane were introduced into a bomb to be hydrogenated. The mixture was stirred at room temperature then $120 \mathrm{mg}$ of 4 -aminoveratrole and $2 \mathrm{ml}$ of triethylamine were introduced. After homogenization of the medium, it was left to react for 24 hours at $120^{\circ} \mathrm{C}$. A black plastic paste was obtained. It was washed several times with distilled water and then with diethyl ether to give a new black color material $\mathrm{P}_{2}$ with a mass of $5.33 \mathrm{~g}$.

\section{Synthesis of polymer $P_{3}$}

$5 \mathrm{~g}$ of commercial PVC $\left(\mathrm{P}_{0}\right), 1.16 \mathrm{~g}$ of $\mathrm{KI}$ and $100 \mathrm{ml}$ of 1,4-dioxane were introduced into a bomb to be hydrogenated. The mixture was stirred at room temperature then $130 \mathrm{mg}$ of 4 -aminophenol and $2 \mathrm{ml}$ of triethylamine were introduced. After homogenization of the medium, it was left to react for 24 hours at $120^{\circ} \mathrm{C}$. A black plastic paste was obtained. It was washed several times with distilled water and then with diethyl ether to give a new material $\mathrm{P}_{3}$ with a mass of $4.85 \mathrm{~g}$ and a black color.

\section{Synthesis of polymer $P_{4}$}

$1 \mathrm{~g}$ of PVC modified by 4 -amino phenol $\left(\mathrm{P}_{2}\right), 70 \mathrm{ml}$ of 1,2-dioxin and $0.5 \mathrm{~g}$ of $\mathrm{KI}$ were introduced into a bomb to be hydrogenated. The mixture was stirred at room tem- 
perature and then $9 \mathrm{ml}$ of diethylene triamine (DETA) and 3 drops of trietylamine were introduced.

After homogenization of the medium, it was left to react for 24 hours at $100^{\circ} \mathrm{C}$. A light brown plastic paste was obtained. It was washed with an aqueous solution of $\mathrm{NaOH}$ of $10^{-2} \mathrm{~mol} / \mathrm{L}$ concentration, then washed several times with distilled water until the filtrate reached the electrical conductivity of distilled water and finally washed with diethyl ether. A new material $\mathrm{P}_{4}$ with a mass of $0.56 \mathrm{~g}$ and a light brown color was obtained.

\section{Proposed structure for polymer $P_{1}$}

Based on the analysis methods, the following structure is proposed for polymer $\mathrm{P}_{1}$ (Scheme $\left.\mathrm{A}\right)$.

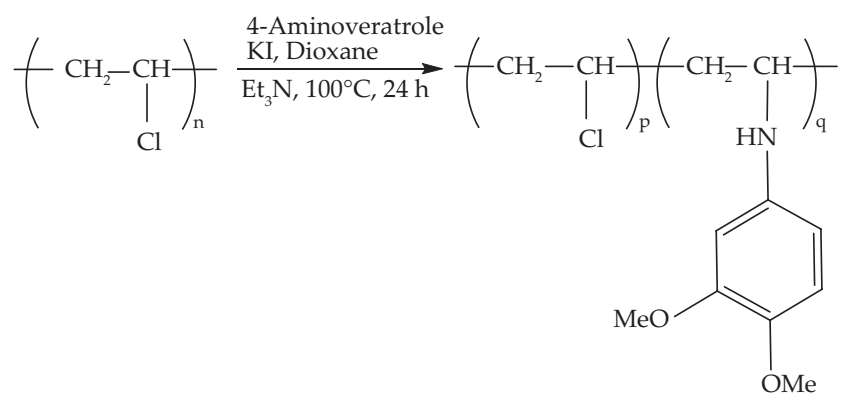

\section{Proposed structure for polymer $P_{2}$}

Based on the analysis methods, the following structure is proposed for polymer $\mathrm{P}_{2}$ (scheme $\mathrm{B}$ ).

\section{Proposed structure for polymer $\mathbf{P}_{3}$}

Based on the analysis methods, the following structure is proposed for polymer $\mathrm{P}_{3}$ (scheme $\mathrm{C}$ ).

\section{Proposed structure for polymer $\mathbf{P}_{4}$}

Based on the analysis methods, the following structure is proposed for polymer $\mathrm{P}_{4}$ (scheme D).

\section{RESULTS AND DISCUSSION}

\section{IR spectroscopy}

IR spectroscopic analysis of the modified polymer $\left(\mathrm{P}_{4}\right)$ clearly shows that a substitution reaction takes place, as indicated by the appearance of characteristic bands of the amino groups at 3390 and $3400 \mathrm{~cm}^{-1}$ corresponding to $\mathrm{NH}_{2}$, as well as an absorption at $1650 \mathrm{~cm}^{-1}$ corresponding to the bending of $\mathrm{NH}$ in the plane. An absorption at $1431 \mathrm{~cm}^{-1}$ is also observed, corresponding to an aromatic $\mathrm{C}=\mathrm{C}$, which confirms he presence of the benzene ring in the polymer

\section{Scheme A}

$$
\left(\left.\right|_{\mathrm{Cl}} ^{\mathrm{CH}_{2}-\mathrm{CH}}\right)_{\mathrm{n}} \frac{\stackrel{\text { 4-Aminoveratrole }}{\mathrm{KI} \text { Dioxane }}}{\mathrm{Et}_{3} \mathrm{~N}, 120^{\circ} \mathrm{C}, 24 \mathrm{~h}}\left(-\mathrm{CH}_{\mathrm{Cl}}^{\mathrm{CH}}\right)_{\mathrm{r}}\left(\mathrm{CH}_{\mathrm{O}}\right.
$$

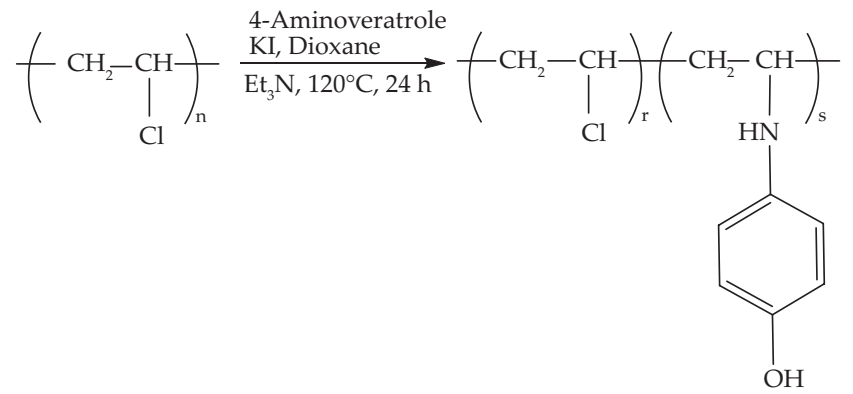

Scheme B

Scheme D

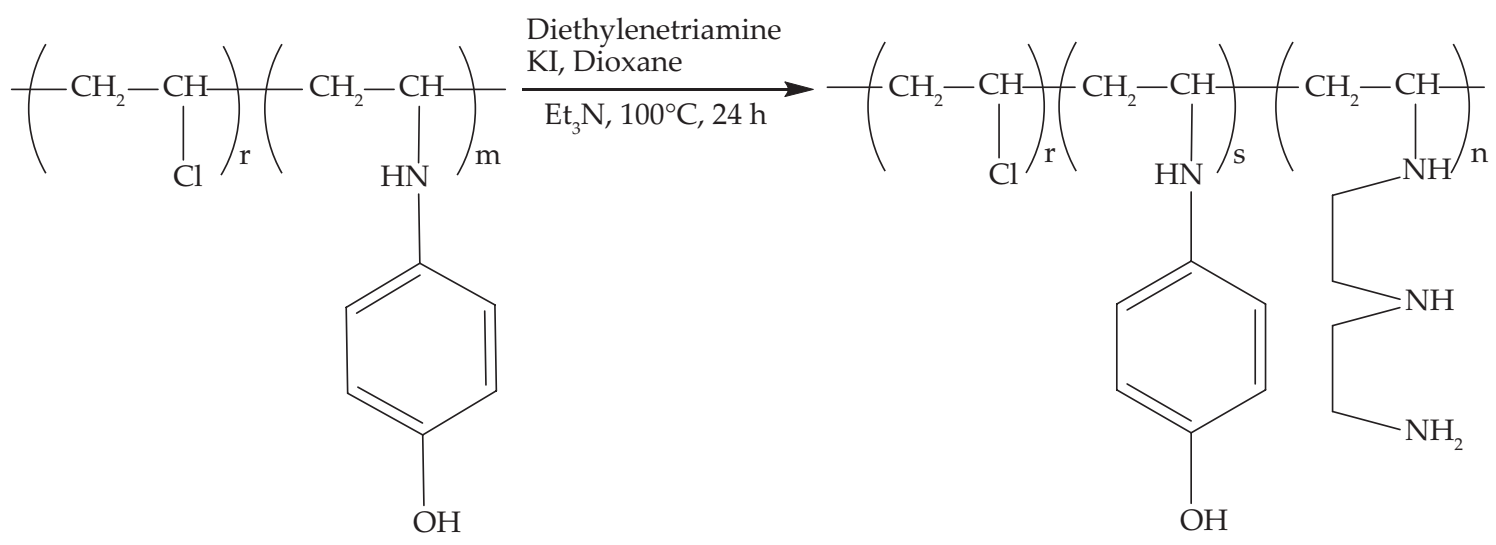




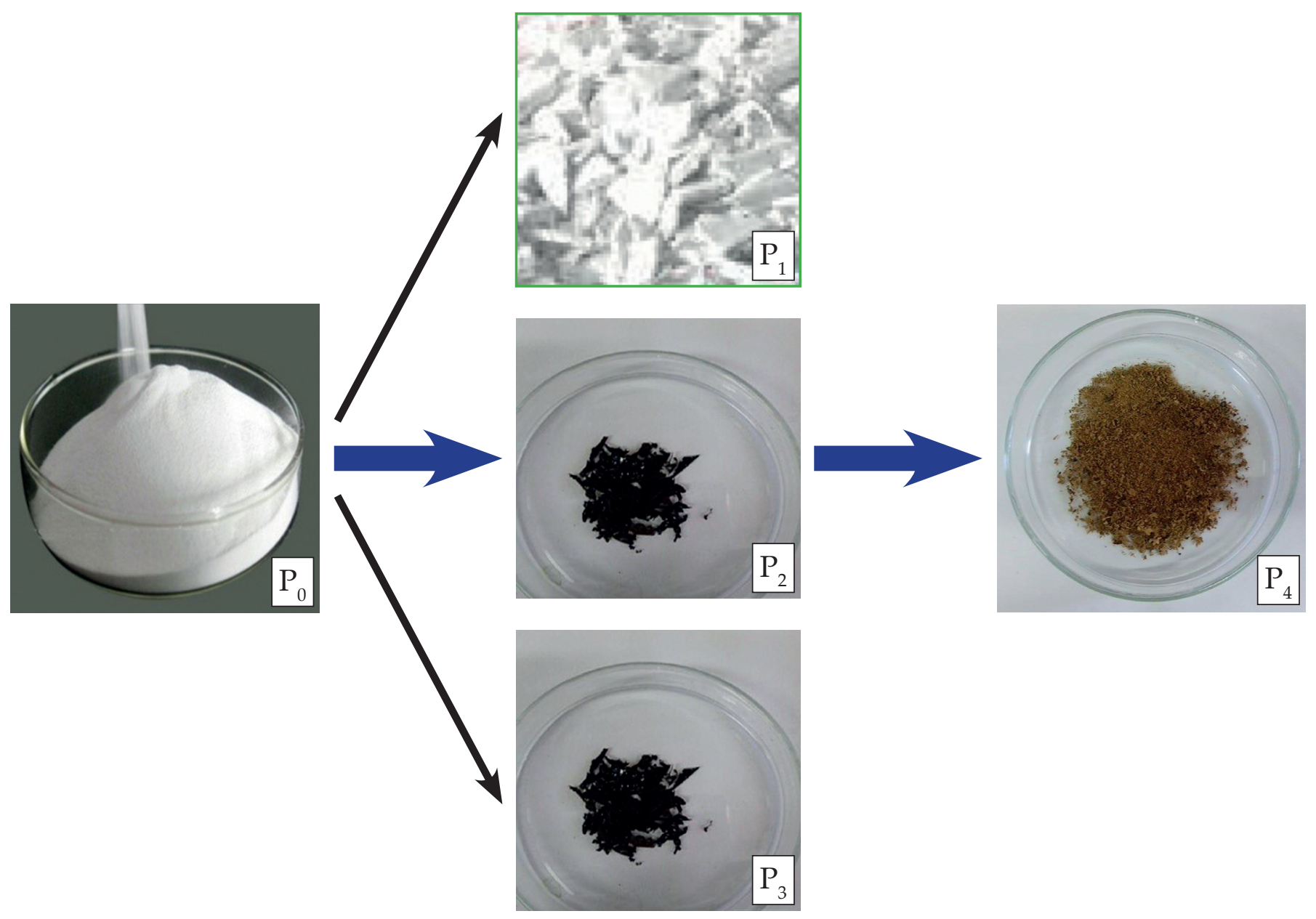

Fig. 1. Polymers obtained after chemical modification of commercial PVC

chains of PVC. All the characteristic bands observed for P1 were also seen in the FT-IR spectrum of $\mathrm{P}_{2}$ and $\mathrm{P}_{3}$ (Fig. 2). However; the spectrum also shows the presence of the weak stretching vibration of chlorine $\left(\mathrm{v}_{\mathrm{C}-\mathrm{Cl}}\right)$ at $690 \mathrm{~cm}^{-1}$, indicating that the chlorine atoms have not entirely disappeared. Results are consistent with those of Ammari et al. [13].

The IR spectra of the polymers $\mathrm{P}_{1}, \mathrm{P}_{2}, \mathrm{P}_{3}$ and $\mathrm{P}_{4}$ are given in the following figure.

a)

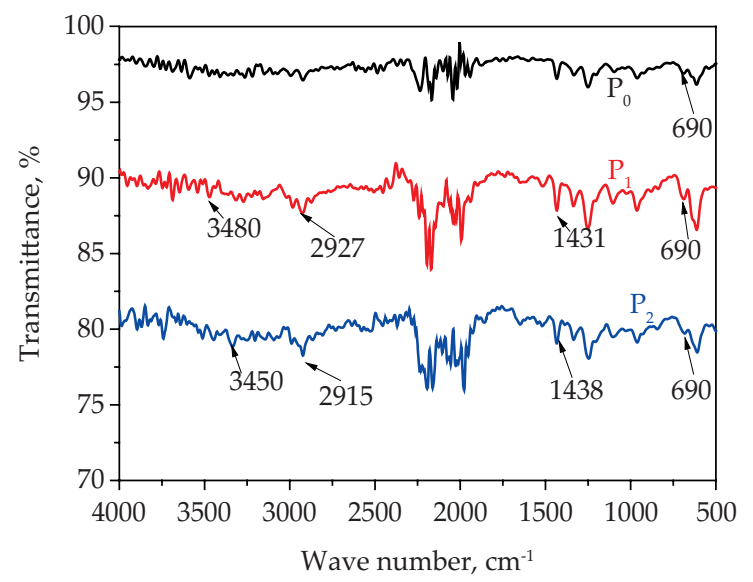

Fig. 2. FT-IR spectra of polymers: a) $P_{0^{\prime}}, P_{1}, P_{2}$; b) $P_{0^{\prime}}, P_{3^{\prime}}, P_{4}$
Comparison of FT-IR spectra for $\mathrm{P}_{1} \mathrm{P}_{2} \mathrm{P}_{3}$ and $\mathrm{P}_{4}$ together with that of $\mathrm{P}_{0}$ clearly shows the modification of $\mathrm{P}_{0}$ since the $\mathrm{P}_{0}$ spectrum has absorption bands at $690 \mathrm{~cm}^{-1}$, corresponding to the $\mathrm{C}-\mathrm{Cl}$ band, and the two absorption bands at $2927 \mathrm{~cm}^{-1}$ for symmetric and asymmetric $\mathrm{CH}_{2}$, middle band respectively, which are only present in $\mathrm{P}_{0}$ (Table 1 ). Finally, the absence of the chlorine stretching vibration band $\left(v_{\mathrm{C}-\mathrm{Cl}}\right)$ between 600 and $800 \mathrm{~cm}^{-1}$ in the $\mathrm{P}_{4}$ spectra

b)

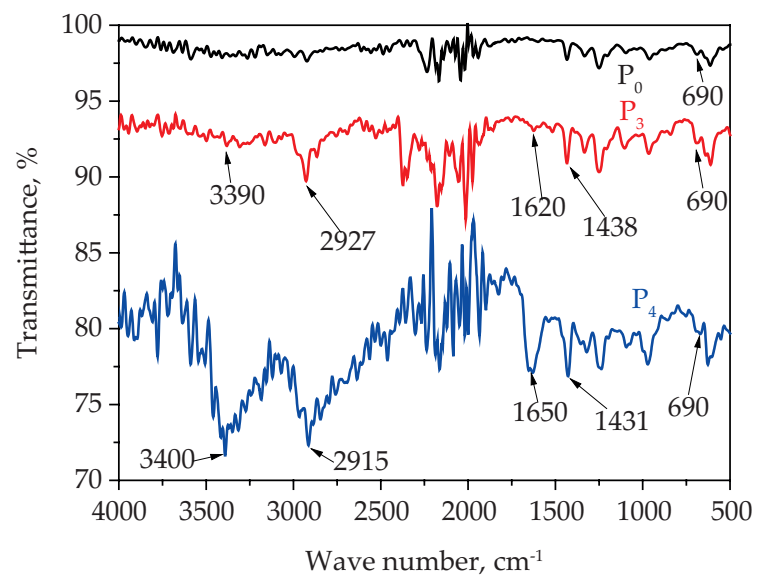


T a b l e 1. FT-IR spectroscopic data for $P_{0}$ and modified polymers $P_{1}, P_{2}, P_{3}$ and $P_{4}$

\begin{tabular}{l|c|c|c|c|c}
\hline \multicolumn{1}{c}{$\begin{array}{c}\text { Characteristic } \\
\text { vibration }\end{array}$} & \multicolumn{5}{c}{ Wave number, $\mathrm{cm}^{-1}$} \\
\cline { 2 - 6 } & $\mathrm{P}_{0}$ & $\mathrm{P}_{1}$ & $\mathrm{P}_{2}$ & $\mathrm{P}_{3}$ & $\mathrm{P}_{4}$ \\
\hline -C-Cl vibration & 690 & 690 & 690 & - & - \\
-CH2 asymmetric and symmetric vibrations & $2930-2860$ & $2930-2860$ & $2930-2860$ & $2930-2860$ & $2930-2860$ \\
-NH2 asymmetric and symmetric vibrations & - & $3300-3400$ & $3300-3450$ & $3300-3390$ & $3330-3400$ \\
C=C aromatic & - & 1431 & 1438 & 1438 & 1431 \\
N-H bending & - & - & 1630 & 1620 & 1650 \\
\hline
\end{tabular}

confirms that the chlorine atoms have been substituted by diethylenetriamine [14].

\section{DTA analysis}

The DTA diagram of commercial PVC $\left(\mathrm{P}_{0}\right)$ shows a melting point at $270^{\circ} \mathrm{C}$ with the absence of an exothermic peak up to $400^{\circ} \mathrm{C}$; it also exhibits a glass transition around $80^{\circ} \mathrm{C}$. That of polymer $\mathrm{P}_{1}$ exhibits 2 endothermic transformations at $88.94 .360^{\circ} \mathrm{C}$ with no exothermic peak up to $400^{\circ} \mathrm{C}$. In the case of polymer $\mathrm{P}_{2^{\prime}}$, we note the presence of an endothermic transformation at $77^{\circ} \mathrm{C}$ and an exothermic peak at $240^{\circ} \mathrm{C}$. Finally, the diagram for polymer $\mathrm{P}_{3}$ shows two peaks, one exothermic at $180.40^{\circ} \mathrm{C}$ and the other endothermic at $341^{\circ} \mathrm{C}$. The $\mathrm{P}_{4}$ diagram shows 2 endothermic transformations at 160 and $260^{\circ} \mathrm{C}$. The peaks around $80^{\circ} \mathrm{C}$ are attributed to the departure of the surface solvent molecules, those at around $160^{\circ} \mathrm{C}$ are due to the departure of amino groups grafted onto the PVC backbone and the peaks around $250^{\circ} \mathrm{C}$ show the continuation of decomposition of polymers (Fig. 3). Note that these thermal behaviors are similar to those found by Ammari et al. [13-15].

The DTA diagrams of the $\mathrm{P}_{1}-\mathrm{Li}^{+}$and $\mathrm{P}_{3}-\mathrm{Li}^{+}$complexes respectively show the presence of an exothermic peak at around $190^{\circ} \mathrm{C}$ and an endothermic peak at around $236^{\circ} \mathrm{C}$, the latter corresponding to the decomposition of the polymer. On the other hand, we note that for the $\mathrm{P}_{4}-\mathrm{Li}^{+}$complex, the appearance of two endothermic peaks around $180^{\circ} \mathrm{C}, 267^{\circ} \mathrm{C}$. By comparison with the diagrams of free polymers, there is a slight shift in the temperatures of the various transformations following this complexation (Figs 4, 5). Likewise an endothermic peak around $275^{\circ} \mathrm{C}$ for $\left(\mathrm{P}_{4}-\mathrm{Cd}^{2+}\right)$ which has a slight transformation compared to $\mathrm{P}_{4}-\mathrm{Li}^{+}$has been attributed to the decomposition of the polymer [14, 15].

\section{Proposed structures of $\mathbf{P}_{4}$}

Various analyzes of denatured polymers $\left(\mathrm{P}_{4}\right)$ have shown the transformation of commercial PVC $\left(\mathrm{P}_{0}\right)$ into 4-aminophenole substitution reactions. A possible structure of $\mathrm{P}_{4}$ is shown in Scheme E (a) and (b). Several chlorine atoms are always present in the proposed structures. The IR spectra of $\mathrm{P}_{4}$ showed that the elongation and oscillation bands of chlorine $\left(\mathrm{v}_{\mathrm{C}-\mathrm{Cl}}\right)$ did not disappear completely. This indicates the presence of several chlorine atoms in the $\mathrm{P}_{4}$ structure returned to the structure proposed by Mbarki et al. [14]. a)

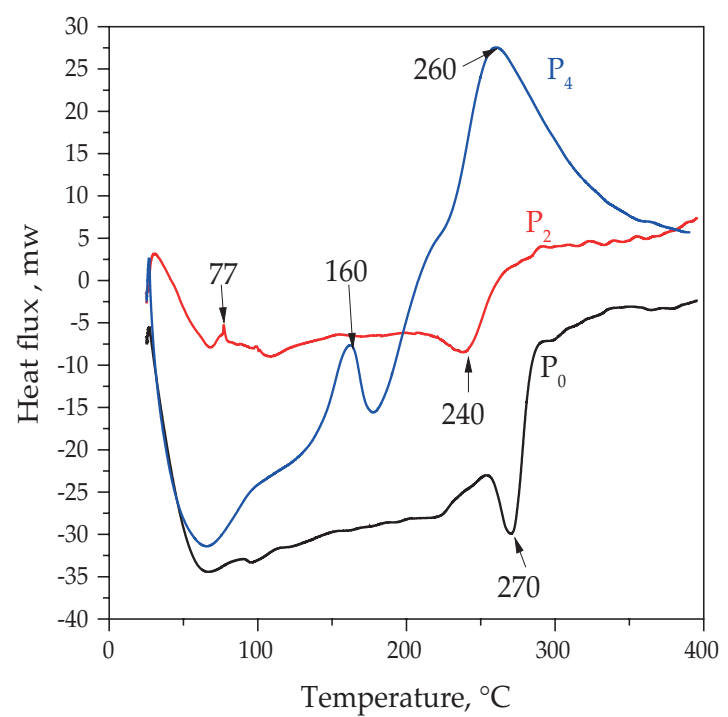

b)

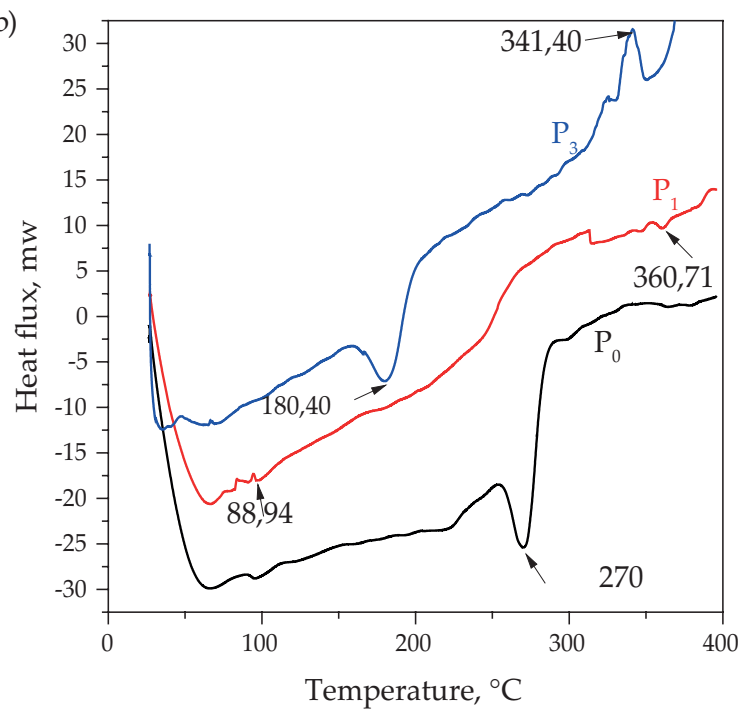

Fig. 3. DTA of polymers: a) $P_{0^{\prime}} P_{2^{\prime}}, P_{4} ;$ b) $P_{0^{\prime}}, P_{1}, P_{3}$ 


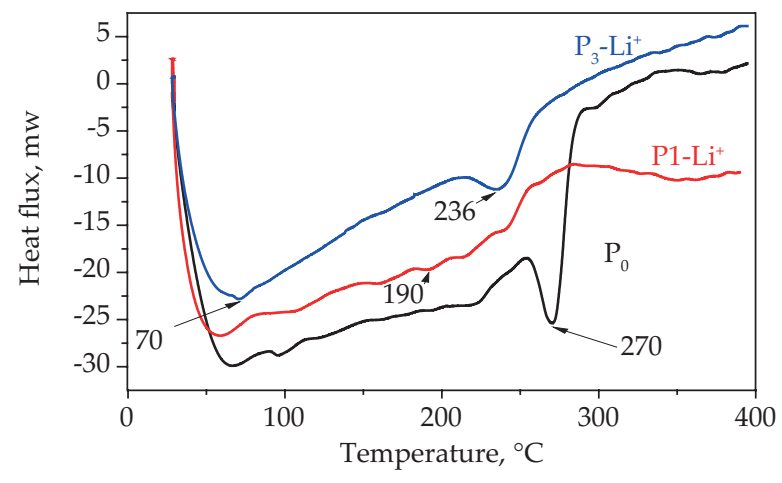

Fig. 4. DTA of polymers: a) $\mathrm{P}_{0^{\prime}}, \mathrm{P}_{1}-\mathrm{Li}^{+}, \mathrm{P}_{3}-\mathrm{Li}^{+}$; b) $\mathrm{P}_{0^{\prime}}, \mathrm{P}_{2}-\mathrm{Li}^{+}, \mathrm{P}_{4}-\mathrm{Li}^{+}$

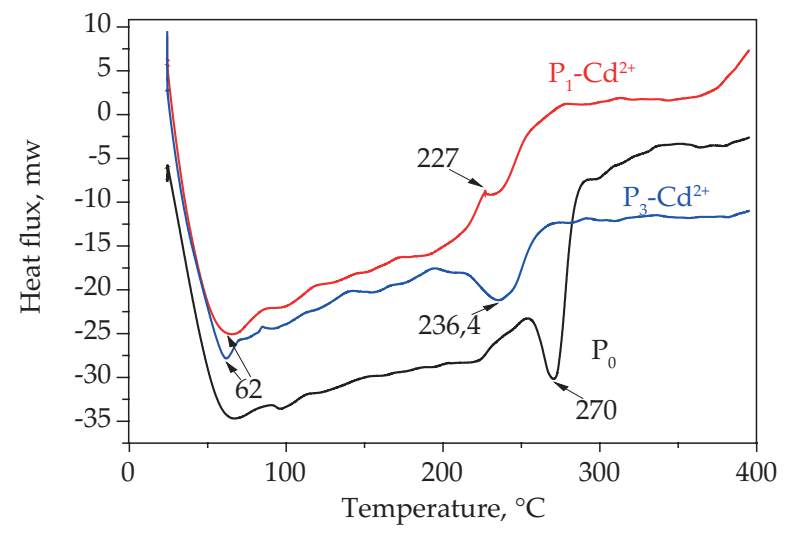

Fig. 5. DTA of polymers: a) $P_{0}, P_{1}-C d^{2+}, P_{3}-C d^{2+}$; b) $P_{0}, P_{2}-C d^{2+}, P_{4}-C d^{2+}$<smiles>CCC(Cl)CC(Cl)CC(Cl)CC(Cl)CC(Cl)CC(Cl)CC</smiles>

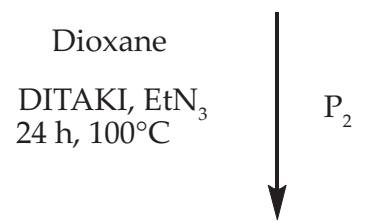<smiles>CCC(CC(Cl)CC(CC(Cl)CC(CC(CC(C)(C)C)NCCNCCN)Nc1ccc(O)cc1)Nc1ccc(O)cc1)NCCN</smiles>

or

Scheme E

\section{Metal cation extraction using modified polymers}

\section{Kinetic study}

Figure 6 below shows the variation of the electrical conductivity as a function of time respectively with $\mathrm{P}_{1^{\prime}}$ $\mathrm{P}_{2}, \mathrm{P}_{3}$ and $\mathrm{P}_{4}$.
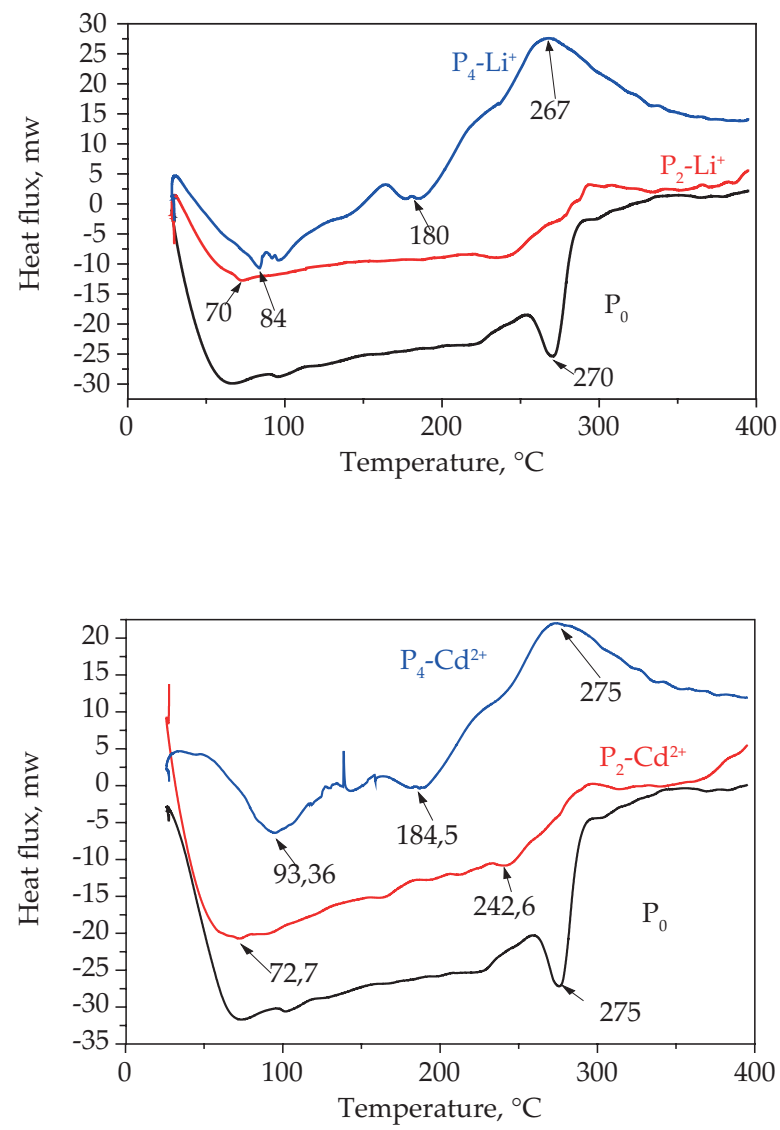<smiles>CCC(CC)CC(Cl)CC(CC(Cl)CC(CC)NCCNCCN)Nc1ccc(O)cc1</smiles>

The curves representing the change in conductivity in various aqueous solutions over time show that the conductivity decreases and then after a period $\Delta$ t remains constant. $\Delta t$ represents the optimal duration of extraction (table 2). The results show that the optimal duration of $\mathrm{Li}+$ cation extraction is the shortest with the four polymers. This is probably due to its small size, thus facilitating its extraction. 
T a b l e 2. Optimal extraction time with polymers $P_{1}, P_{2}, P_{3}$ and $P_{4}$

\begin{tabular}{c|c|c|c|c}
\hline \multicolumn{1}{c|}{ Polymers } & $\mathrm{P}_{1}$ & $\mathrm{P}_{2}$ & $\mathrm{P}_{3}$ & $\mathrm{P}_{4}$ \\
\hline Optimal duration for $\mathrm{Li}^{+}, \mathrm{h}$ & 26 & 30 & 34 & 36 \\
Optimal duration for $\mathrm{Cd}^{2+}, \mathrm{h}$ & 40 & 100 & 135 & 155 \\
\hline
\end{tabular}

a)

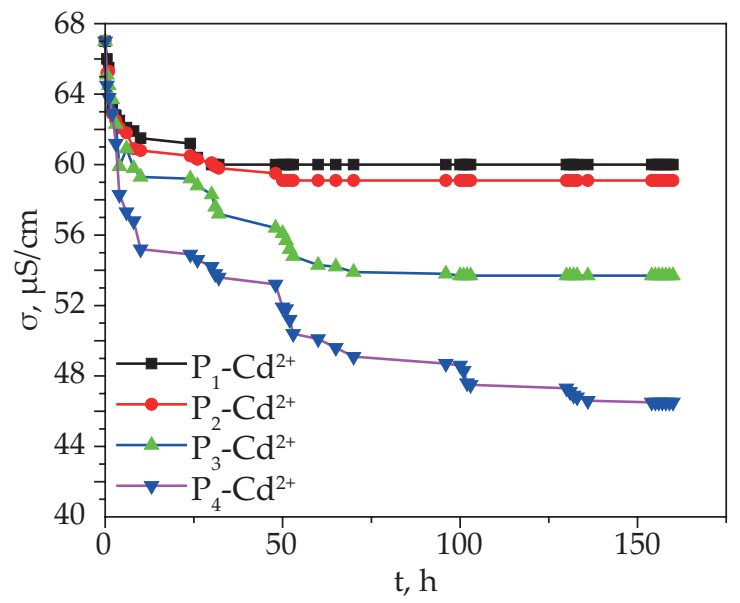

b)

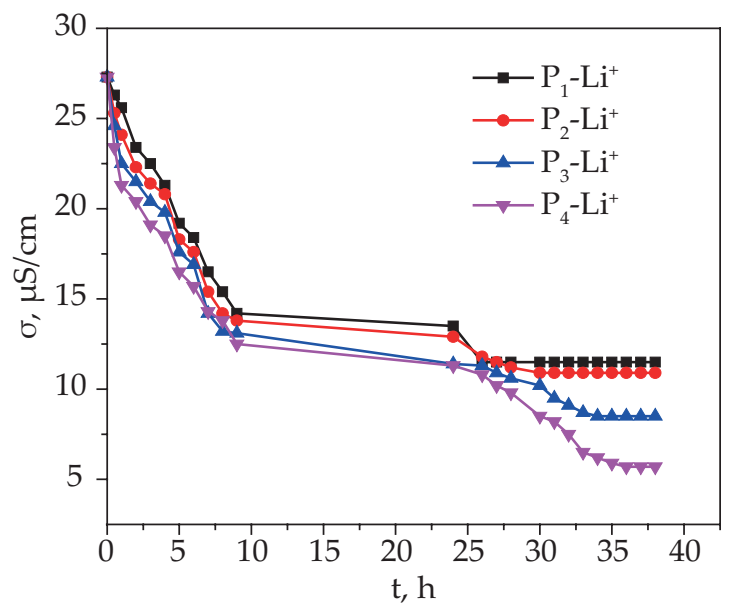

Fig. 6. Conductivity variation curves over time for some cations: a) $\left.P_{1}-C^{2+}, P_{2}-C^{2+}, P_{3}-C^{2+}, P_{4}-C^{2+} ; b^{2}\right) P_{1}-L_{i}^{+}, P_{2}-L^{+}, P_{3}-L^{+}, P_{4}-L^{+}$

\section{Interpretation}

Figure 7 summarizes the percentage of metal cations removal with the studied materials $\mathrm{P}_{1}, \mathrm{P}_{2}, \mathrm{P}_{3}$ and $\mathrm{P}_{4}$. These results are the average of three experiments for each studied metal. These results show that the material $\mathrm{P}_{4}$ is the best extractant of $\mathrm{Li}^{+}$and $\mathrm{Cd}^{2+}$ ions with respective extraction efficiency $87.17 \%$ and $28.65 \%$. This confirms the structures proposed in scheme E since the material $\mathrm{P}_{4}$ corresponds to a greater number of substituted chlorine atoms compared to $\mathrm{P}_{2}$. The presence of oxygen atoms, due to the introduction of amino phenol groups into the structure of $\mathrm{P}_{4}$ confirmed by IR analysis, promotes the extraction of these metal cations which is in agreement with the theory of hard and soft acid bases (HSAB) since oxygen atoms are hard bases and therefore has affinities for these hard acids.

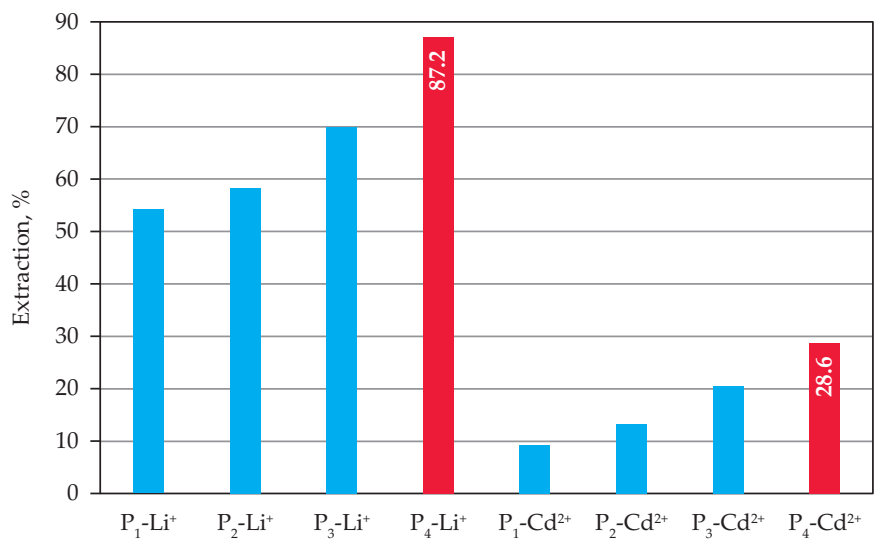

Fig. 7. Histogram of extraction degrees

\section{Atomic absorption spectrometry (AAS)}

\section{Method of analysis}

In this work, an atomic absorption spectrometry was used for determination of metals using the PerkinElmer... Pin AAcle $900 \mathrm{~T}$ spectrometer.

The calibration of the spectrometer was performed using standard solutions for each metal. The calibration range was between 0.2 and 2 ppm.

\section{Interpretation}

Table 3 shows the extraction percentages obtained by conductivity measurements and by AAS for the studied metals.

The absorption method gives higher extraction degrees than those found with conductivity. The differences between the extraction degrees obtained by the 2 methods varied between $8 \%$ and $12 \%$.

\section{Proposed structures of $\mathrm{P}_{4}-\mathrm{Li}^{+}$}

Complexation with $\mathrm{Li}^{+}$and $\mathrm{Cd}^{2+}$ was the best for $\mathrm{P}_{4}$ since the extraction degrees were $87.17 \%$ and $28.65 \%$ respectively, compared to $\mathrm{P}_{1}, \mathrm{P}_{2}$ and $\mathrm{P}_{3}$ for which extraction percentages vary from $54.21 \%$ to $69.96 \%$ for $\mathrm{Li}^{+}$and from $9.4 \%$ to $20.59 \%$ for $\mathrm{Cd}^{2+}$ (Table 3). This type of complex structures is well known in supramolecular chemistry [18]. These results can be explained by the compatibility between the size of the metal ion and the size of the complexing cavity and the type of heteroatom ligands (oxygen and nitrogen atoms). This type of atom $(\mathrm{N}, \mathrm{O})$ is capable 
$\mathrm{T}$ a b l e 3. Extraction efficiency obtained with conductivity and atomic absorption spectrometry (AAS)

\begin{tabular}{c|c|c|c|c|c|c|c|c}
\hline \multirow{2}{*}{$\begin{array}{c}\text { Metal } \\
\text { cation }\end{array}$} & \multicolumn{2}{|c|}{$\begin{array}{c}\text { Degree of extraction } \\
\text { with } \mathrm{P}_{1}\end{array}$} & \multicolumn{2}{c|}{$\begin{array}{c}\text { Degree of extraction } \\
\text { with } \mathrm{P}_{2}\end{array}$} & \multicolumn{2}{c|}{$\begin{array}{c}\text { Degree of extraction } \\
\text { with } \mathrm{P}_{3}\end{array}$} & \multicolumn{2}{c}{$\begin{array}{c}\text { Degree of extraction } \\
\text { with } \mathrm{P}_{4}\end{array}$} \\
\cline { 2 - 10 } & Conductivity & AAS & Conductivity & AAS & Conductivity & AAS & Conductivity & AAS \\
\hline $\mathrm{Li}^{+}$ & 54.21 & 62.3 & 58.24 & 67.2 & 69.96 & 78.1 & 87.17 & 95.5 \\
$\mathrm{Cd}^{2+}$ & 9.4 & 21.40 & 13.24 & 25.28 & 20.59 & 30 & 28.65 & 38.7 \\
\hline
\end{tabular}<smiles>COc1ccc(NC(C)CCCC(C)C)cc1NC(C)CCCC(C)Nc1ccc(OC)c(OC)c1</smiles>

or

Scheme F

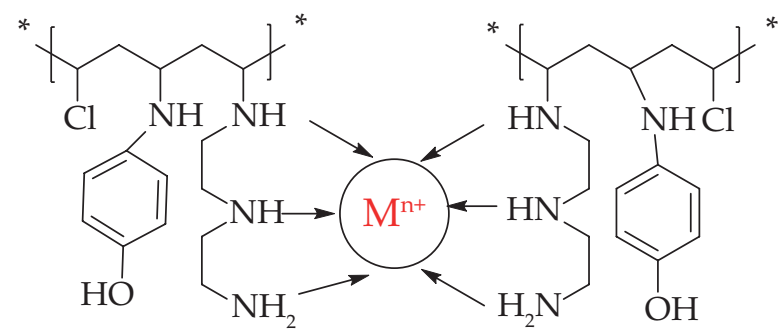

Scheme G

of fixing the metal by non-covalent bonds (van der Waals bonds). Depending on the structures there are different types of macrocyclic complexing cavities (scheme F, G). The retention of metal cations can al'so be explained by the presence of an electron-rich $\pi$ system (benzene ring), this type of interaction has been explained by the theory of non-covalent cation- $\pi$ interactions [14-19].

\section{Influence of complexation in IR spectroscopy}

In order to study the influence of complexation on the structure of polymers, the IR spectra of the $\mathrm{P}_{\mathrm{i}}-\mathrm{Li}^{+}$and Pi- $\mathrm{Cd}^{2+}$ complexes are given in Figs 8, 9 .

The IR absorption spectra of the studied complexes (Figure 8 ) indicate a slight shift in the characteristic bands of the amines which are linked by coordination bonds to the to the metal ion, but the influence of the complexes on the IR spectra is not very significant. This could be due to the counter-anions of the metal cations, because of the use of these salts: $\mathrm{CdCl}_{2}$, $\mathrm{H}_{2} \mathrm{O}$; $\mathrm{Li} \mathrm{Br}$, which strongly bind water molecules making it difficult to interpret these spectra. But we note the extension of the band at $3359 \mathrm{~cm}^{-1}$ due to the complexation of the polymers and the increase in the band at $1631 \mathrm{~cm}^{-1}$.

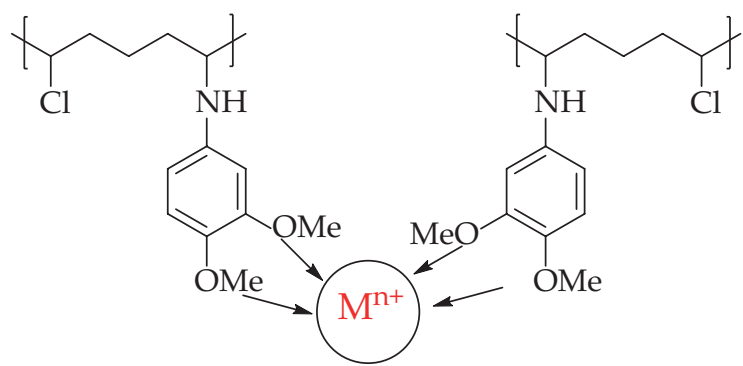

CONCLUSIONS

This work allowed us to obtain four new materials by functionalization of a PVC $(\mathrm{Mw}=48000)$ noted respectively $\mathrm{P}_{1}, \mathrm{P}_{2}, \mathrm{P}_{3}$ and $\mathrm{P}_{4}$. The procedure for preparing the reactions depends on the used solvent, the temperature, and the reaction time. These new materials containing electron donor atoms such as nitrogen and oxygen have been used as chelating agents for the extraction of heavy metals. This study shows that increasing the number of substituents through the use of diethylenetriamine improves the properties of functionalized PVC as an extraction agent. This work allowed us to evaluate the extraction of heavy metals by new adsorbents based on modified PVC polymers from aqueous solutions of metal cations. Our next studies will focus on the use of these new materials in the depollution of real wastewater from the Bizerte wastewater treatment plant located in northern Tunisia.

\section{ACKNOWLEDGMENTS}

The authors would like to thank Mr. Fayçel Ammari (Senior Lecturer at Preparatory Institute for Scientific and Technical Studies, Tunisia).

\section{REFERENCES}

[1] Baitz M., Kreißig J., Byrne E. et al.: "Life Cycle Assessment of PVC and of principal competing materials". Commissioned by the European Commission. July, 13-16, 2004.

[2] Sadat-Shojai M., Bakhshandeh G.R.: Polymer Degradation and Stability 2011, 96, 404. 
a)

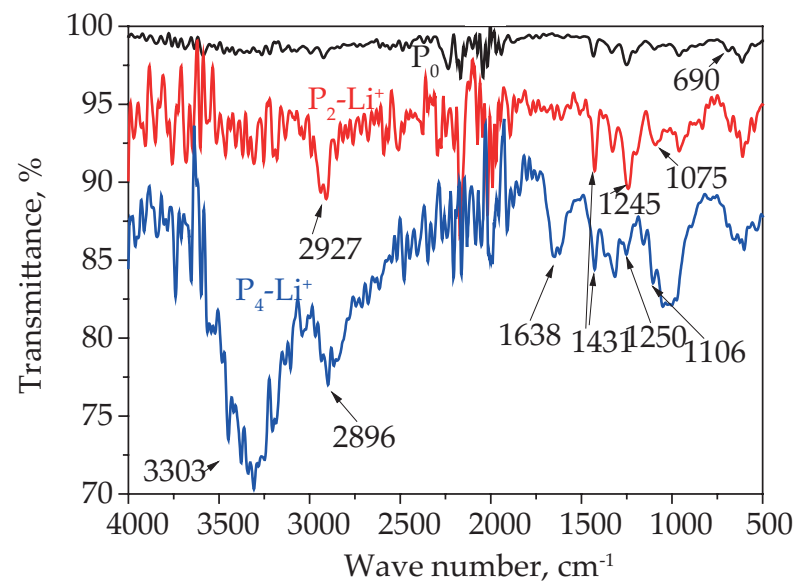

b)

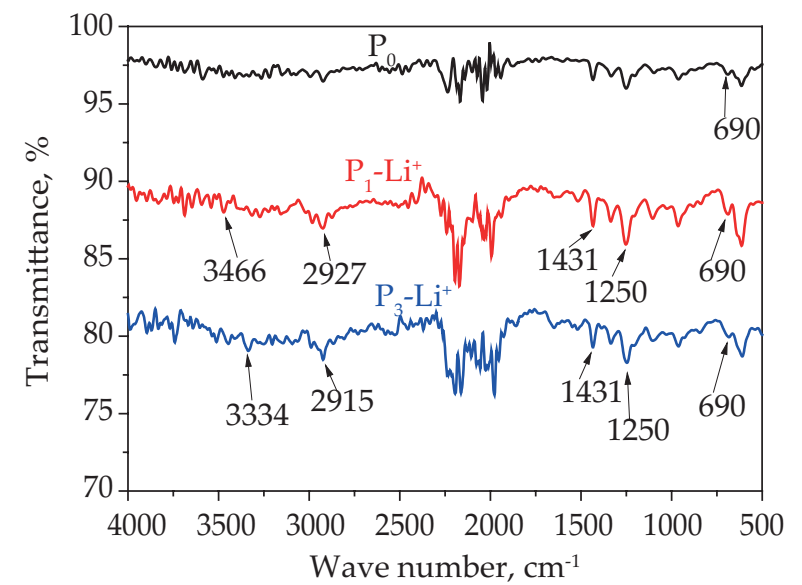

Fig. 8. FT-IR spectra of polymers: a) $\mathbf{P}_{0^{\prime}} \mathbf{P}_{2}-\mathrm{Li}^{+}, \mathbf{P}_{4}-\mathrm{Li}^{+}$; b) $\mathbf{P}_{0^{\prime}} \mathbf{P}_{1^{-}}-\mathrm{Li}^{+}, \mathbf{P}_{3}-\mathrm{Li}^{+}$

a)

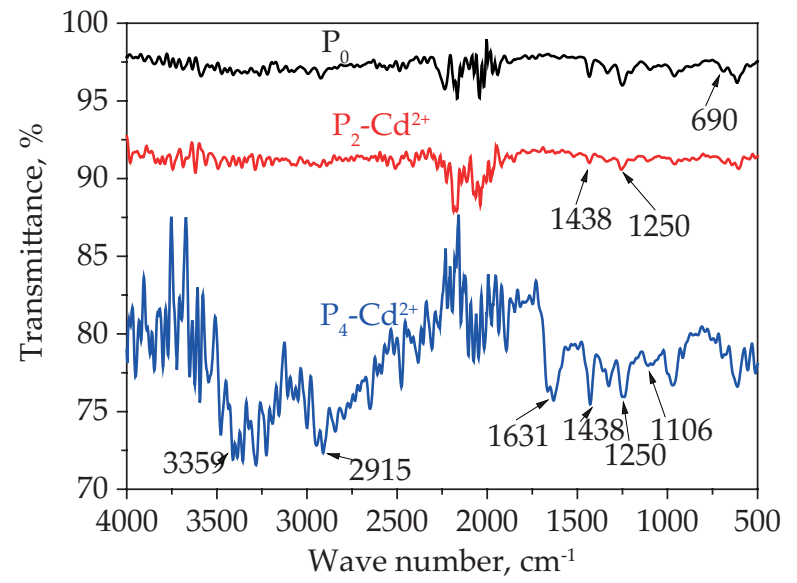

b)

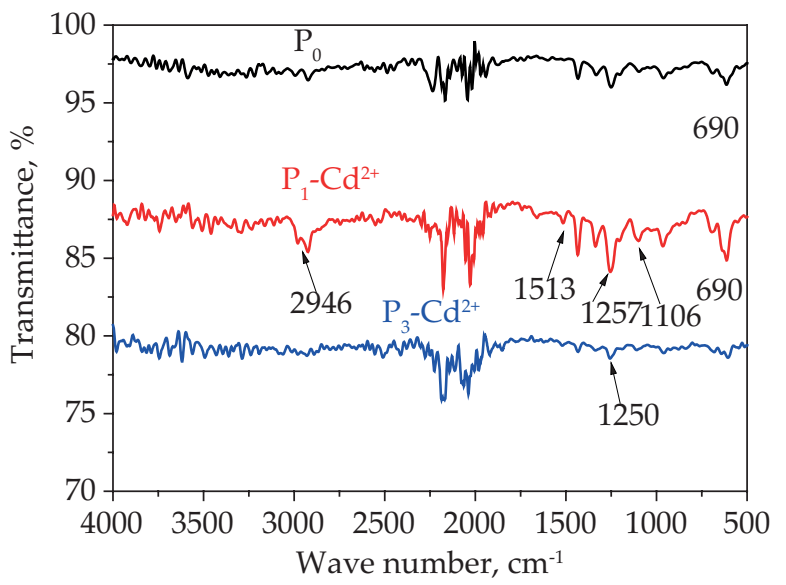

Fig. 9. FT-IR spectra of polymers: a) $\mathrm{P}_{0^{\prime}}, \mathrm{P}_{2}-\mathrm{Cd}^{2+}, \mathrm{P}_{4}-\mathrm{Cd}^{2+}$; b) $\mathrm{P}_{0^{\prime}} \mathrm{P}_{1}-\mathrm{Cd}^{2+}, \mathrm{P}_{3}-\mathrm{Cd}^{2+}$

https://doi.org/10.1016/j.polymdegradstab.2010.12.001

[3] Larm O., Larson R., Olsson P.: Biomaterials, Medical Devices and Artificial Organs 1983, 11, 161. https://doi.org/10.3109/10731198309118804

[4] Yu J.L., Johansson S., Ljungh A.: Biomaterials 1997, 18, 421. https://doi.org/ 10.1016/s0142-9612(96)00154-8

[5] Ferruti P., Barbucci R., Danzo N. et al.: Biomaterials 1982, 3, 33. https://doi.org/10.1016/0142-9612(82)90058-8

[6] Barbucci R., Casini G., Ferruti P., Tempesti F.: Polymer 1985, 26,1349.

https://doi.org/10.1016/0142-9612(85)90071-7

[7] Krishnan V.K., Jayakrishnan A., Francis J.D.: Biomaterials 1991, 12, 482. https://doi.org/ 10.1016/0142-9612(91)90147-3

[8] Ishikawa Y., Honda K., Sasakawa S. et al.: Vox Sanguinis 1983, 45,68. https://doi.org/10.1111/j.14230410.1983.tb04125.x

[9] Won S.W., Kim S., Kotte P. et al.: Journal of Hazardous Materials 2013, 263, 391.

https://doi.org/10.1016/j.jhazmat.2013.09.019
[10] Bilal M., Shah J.A., Ashfaq S.M.H. et al.: Journal of Hazardous Materials 2013, 263, 322.

https://dx doi.org/10.1016/j.jhazmat.2013.07.071

[11] Wei W., Kim S., Song H. et al.: Journal of the Taiwan Institute of Chemical Engineers 2015, 57, 104. https://doi.org/10.1016/j.jtice.2015.05.019

[12] Lee C.H., Jeong M.K., Fatih Kilicaslan M. et al.: Waste Management 2013, 33, 730. https://doi.org/10.1016/j.wasman.2012.10.002

[13] Ammari F., Meganem F.: Turkish Journal of Chemistry 2014, 38, 638. https://doi.org/10.3906/kim-1306-24

[14] Mbarki F., Ammari F., Bel Haj Amor A. et al.: Polimery 2017, 62 (2), 109. https://doi.org/10.14314/polimery.2017.109

[15] Ammari F., Dardouri M., Meganem F.: Desalination and Water Treatment 2016, 57, 19488. https://doi.org/10.1080/19443994.2015.1099475

[16] Chrayet B., Ammari F., Meganem F.: Polimery 2017, 62 (3), 187. https://doi.org/10.14314/polimery.2017.187

[17] Ouerghui A., Ammari A., Girard C.: Polimery 2020, 65, 801. 
https://doi.org/10.14314/polimery.2020.11.7

[18] Ouerghui A., Dardouri M., Sleimimi N. et al.: Polimery 2019, 64, 3.

https://doi.org/10.14314/polimery.2019.1.1

[19] Won Park S., Bediako J., Song M. et al.: Journal of Environmental Chemical Engineering 2018, 18, 3437. https://doi.org/10.1016/j.jece.2018.03.08

[20] Moulay S., Zeffouni Z.: Journal of Polymer Research 2006, 13, 267

https://doi.org/10.1007/s10965-005-9034-6

Received 11 III 2021. 